\title{
METAGABBROS, METASYENITES AND RELATED ROCKS IN THE OUTOKUMPU ASSEMBLAGE, EAST FINLAND
}

\author{
ADRIAN F. PARK
}

PARK, ADRIAN F. 1992: Metagabbros, metasyenites and related rocks in the Outokumpu assemblage, east Finland. Bull. Geol. Soc. Finland 64, Part 1, 91-111.

A diverse group of minor intrusive rocks in the early Proterozoic Outokumpu assemblage of eastern Finland include metagabbro, hornblendite, amphibolite, pyroxenite, syenite and chloritized dykes. All are deformed and/or extensively altered and recrystallized. Intrusive relationships with serpentinite and metavolcanic rocks suggest they include the youngest pre-tectonic rocks in the Outokumpu assemblage. Geochemistry and rare relict mineral assemblages identify one, possibly two suites of minor intrusions that are alkaline in affinity, but not consistently peralkaline, with all but the amphibolites being derived from cumulates. They range from ultramafic diopside \pm olivine rocks, through quartz-dolerite, to diopside + plagioclase + microcline \pm olivine syenites with normative nepheline and leucite. Elevated levels of $\mathrm{Na}, \mathrm{K}$ and $\mathrm{Ca}$ are characteristic, giving the syenitic rocks an apparent kinship with shoshonites, and the most extreme compositions a resemblance to shonkinite. Pervasive carbonation and phlogopitization preceded deformation, and trace element patterns suggest this was a late stage magmatic process with the bulk addition of $\mathrm{CO}_{2}$, rather than bulk assimilation of the carbonate metasediments of the Outokumpu assemblage. The presence of alkaline rocks in the Outokumpu assemblage has profound implications for the original tectonic setting of these rocks, requiring, in particular, modification of the »ophiolite» model. These rocks show broad affinities with undersaturated calc-alkaline rocks of the shoshonite trend towards shonkinites (particularly Group III ultrapotassic igneous rocks), reinforcing an intraoceanic island arc interpretation for part, if not all, the Outokumpu assemblage.

Key words: metagabbro, hornblendite, amphibolites, pyroxenite, syenites, geochemistry, genesis, proterozoic, Kaavi, Juankoski, Finland

Adrian F. Park: Centre for Deformation Studies in the Earth Sciences, Department of Geology, University of New Brunswick, P.O. Box 4400, Fredericton, New Brunswick, Canada, E3B $5 A 3$.

\section{Introduction}

The Outokumpu assemblage (Park, 1984) in the early Proterozoic Svecokarelides of eastern Finland contains the $\mathrm{Cu}-\mathrm{Co}-\mathrm{Zn}$ sulphide ore bodies of the Outokumpu mining district (Väyrynen, 1939; Vähätalo, 1953; Koistinen, 1981). It consists of a distinctive group of serpentinized ultramafic bodies (dunite and saxonite, Haapala,
1936; Park, 1983), mafic metavolcanic amphibolites and greenschists (Park, 1984; Rehtijärvi \& Saastamoinen, 1985), chromium-rich calc-silicate skarns and dolomites, quartz rock (metachert) and metalliferous black schists (carbonaceous sulphidic pelites) (Huhma \& Huhma, 1970; Gaál et al. 1975; Koistinen, 1981; Fig. 1). Within the now extensive literature describing this assemblage (see Park, 1988a for review and references) 


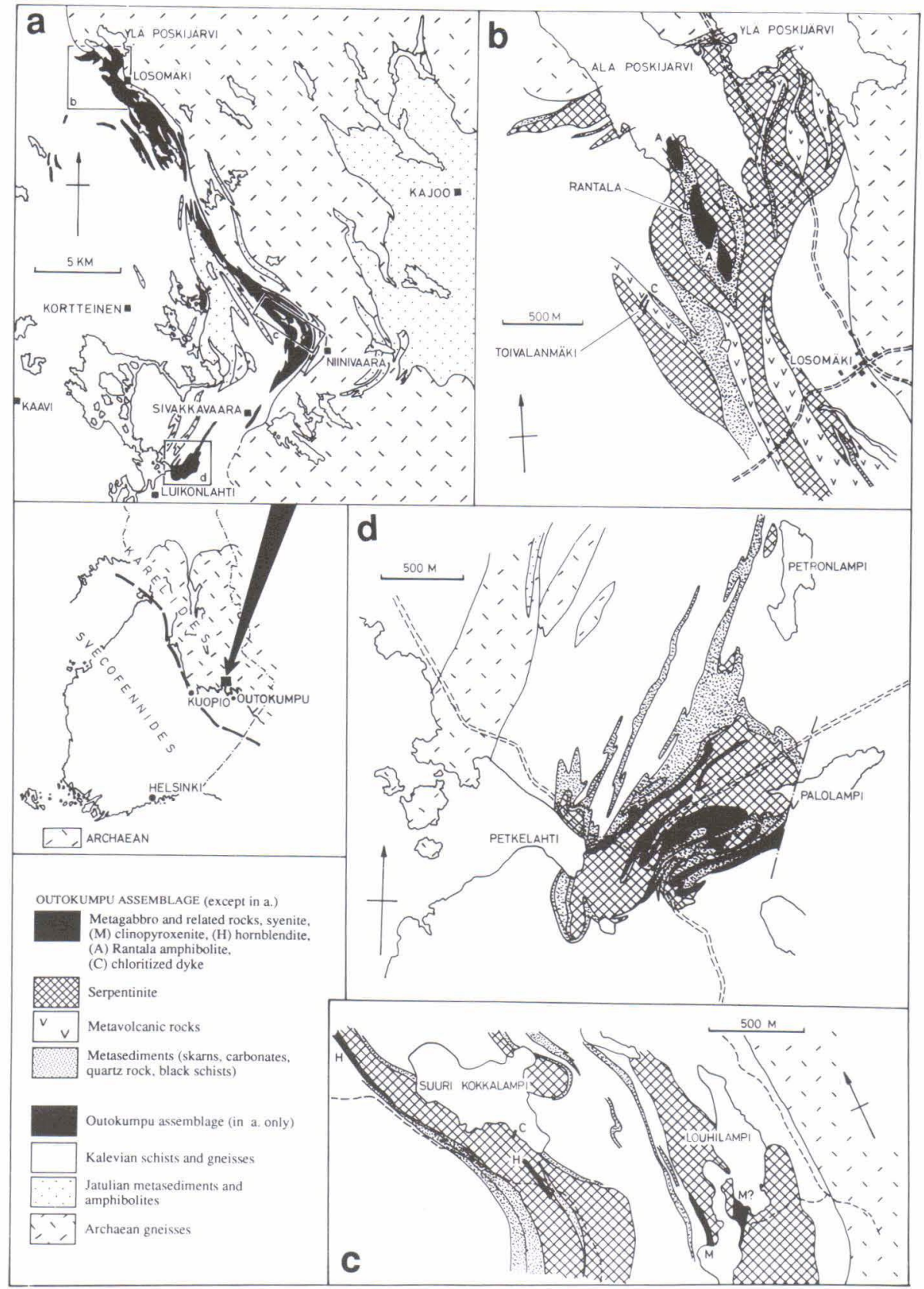

Fig. 1. Geological maps showing the location of metagabbro and related rocks in the Outokumpu assemblage of the Kaavi district, eastern Finland.

a. Outline geology of the area east of Kaavi, with its location in Finland. Geology after Huhma (1971); granitoids are omitted for clarity.

b. Outline geology of the Losomäki area, after Park (1984).

c. Outline geology of the area around the Luikonlahti mine, from data provided by Myllykoski Oy, modified after Park (1988b).

d. Outline geology of the Suuri Kokkalampi and Louhilampi area, after Park (1983). The hornblendite is only seen in borehole core, and its outcrop is approximated by projection. 
passing reference has been made to a diverse group of metamorphosed, altered and deformed intrusive igneous rocks that constitute a minor component of the assemblage at several localities. Some of these rocks have been grouped as »skarns» on the $1: 100,000$ scale geological maps (Huhma, 1971, cf. Fig. 1) reflecting their highly modified nature, and usually referred to as »barren skarn», "hornblende skarn» or »chlorite skarn» by mining and exploration geologists in the area (e.g. Eskelinen et al. 1983) on account of the dearth of sulphide or mineralization in them. Other examples are too minor to be included on the $1: 100,000$ scale geological maps. The chloritized dykes were first reported by Park $(1983,1984)$. To date no systematic or detailed account of the petrography or geochemistry of these rocks has been made.

\section{Petrography}

Petrographically, these rocks fall into five loosely defined groups, metagabbros and their tectonized equivalents, amphibolite, pyroxenites (some of which are feldspathic), syenitic gneiss and chloritized dykes.

\section{Metagabbros and their tectonized equivalents (hornblendite and hornblende schist)}

Gabbroic or metagabbroic rocks are a very rare component of the Outokumpu assemblage, forming bodies with relict igneous texture and mineralogy, such as the Horsmanaho gabbro and related pegmatoid veins around Polvijärvi (15 and $25 \mathrm{~km} \mathrm{NE}$ of Outokumpu, Koistinen 1981; H. Huhma, pers. comm.). Despite their rarity these rocks are especially significant because the age ascribed to the whole assemblage is based on zircon separates from these lithologies (1970 Ma, U-Pb zircon, Koistinen 1981; Huhma 1986). The Horsmanaho body is known only from borehole core and no whole rock geochemistry is available.
It consists of altered and possibly metamorphic plagioclase $\left(\mathrm{An}_{50-65}\right)$ with green hornblende replacing relics of augite. Zircon and ilmenite are accessories, with variable amounts of chlorite also present. The margins of this body are strongly tectonized, constituting a hornblende-chlorite schist with ilmenite. Where pseudomorphs after clinopyroxene survive grain size indicates a truly plutonic rather than hypabyssal protolith.

Similar rocks to the metagabbro-derived schists are known from borehole core at Suuri Kokkolampi, near Niinivaara (Fig. 1, Park 1983). They vary from foliated hornblendite with minor chlorite, to chlorite-dominated schists with minor hornblende. Minor amounts of a phlogopitic biotite occur in the more hornblende-rich material. Most contain more than 2\% (modal) ilmenite, with one sample containing more than $40 \%$. Zircon is a ubiquitous accessory phase. No plagioclase has been reported from these schists (Figs 2a, b, 3).

\section{Amphibolites (Rantala amphibolite)}

As described by Park (1984), these are small bodies of fine-grained, foliated, but not layered, hornblende-plagioclase-quartz rock occurring near Rantala farm, Losomäki (Fig. 1). The rock contains some $50 \%$ green hornblende, $35 \%$ quartz and $15 \%$ calcic plagioclase $\left(\mathrm{An}_{45-55}\right)$. A titanium-bearing magnetite forms a very sparsely distributed accessory phase. There is no direct evidence of primary grain size left in this material, but an absence of primary volcanic features (such as those documented elsewhere in the area, Park 1984) suggests an intrusive origin.

\section{Pyroxenites}

These rocks are often, though not always feldspathic, in one case olivine-bearing, and have been reported from Louhilampi, near Niinivaara (Fig. 1) and from borehole core at Petäjäjärvi (40 kms SSE of Outokumpu; Park 1983). Diopside, usually chromian $\left(0.5-2.5 \quad\right.$ wt $\left.\% \quad \mathrm{Cr}_{2} \mathrm{O}_{3}\right)$, 

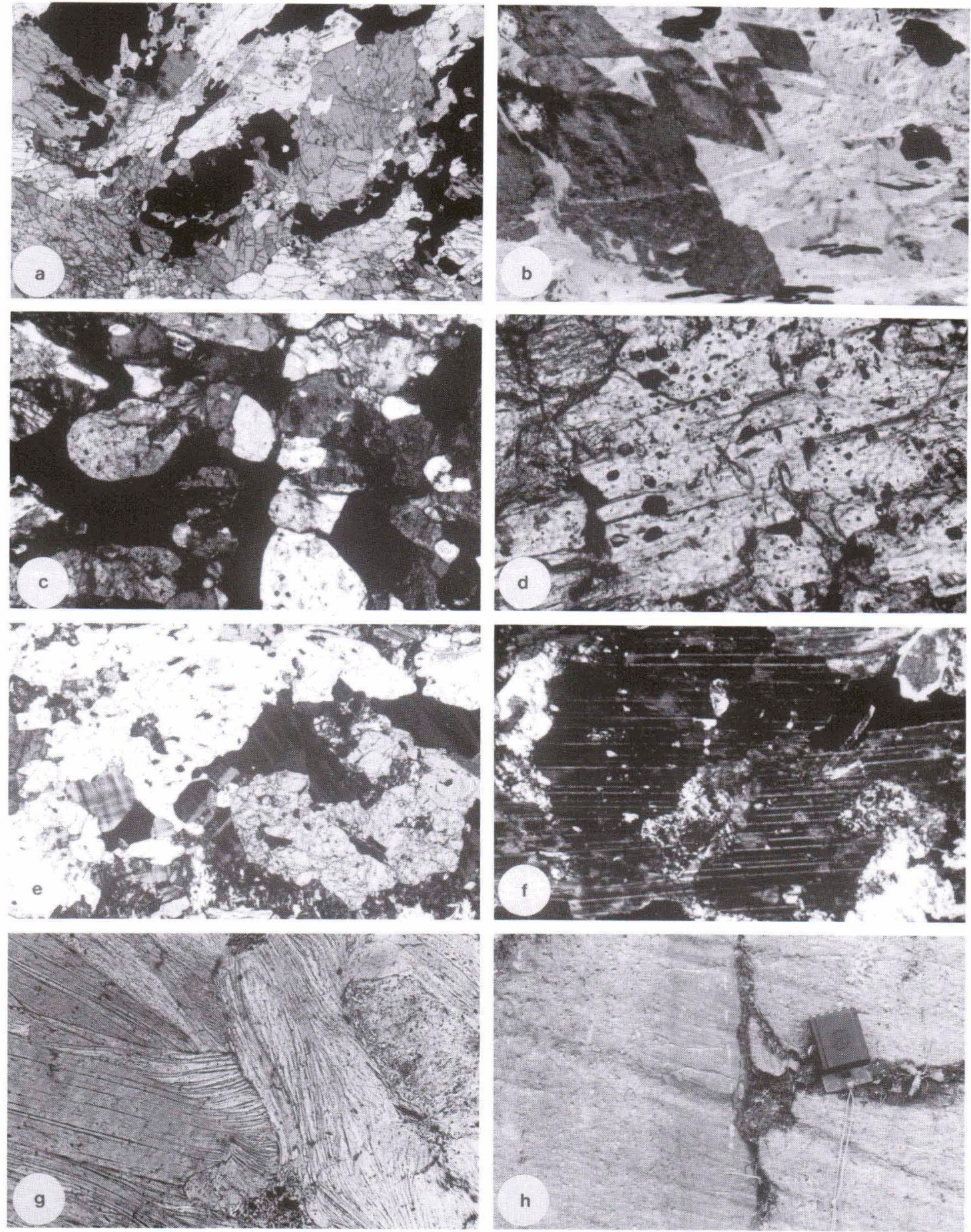

Fig. 2.

a. Ilmenite-bearing coarse hornblendite, from diamond drill-core at Suuri Kokkalampi (Fig. 1d). Field of view $=5 \mathrm{~mm}$ across, plane polarized light. 
Fig. 3. Paragenetic sequences in the metagabbros and other minor intrusions in the Outokumpu assemblage.

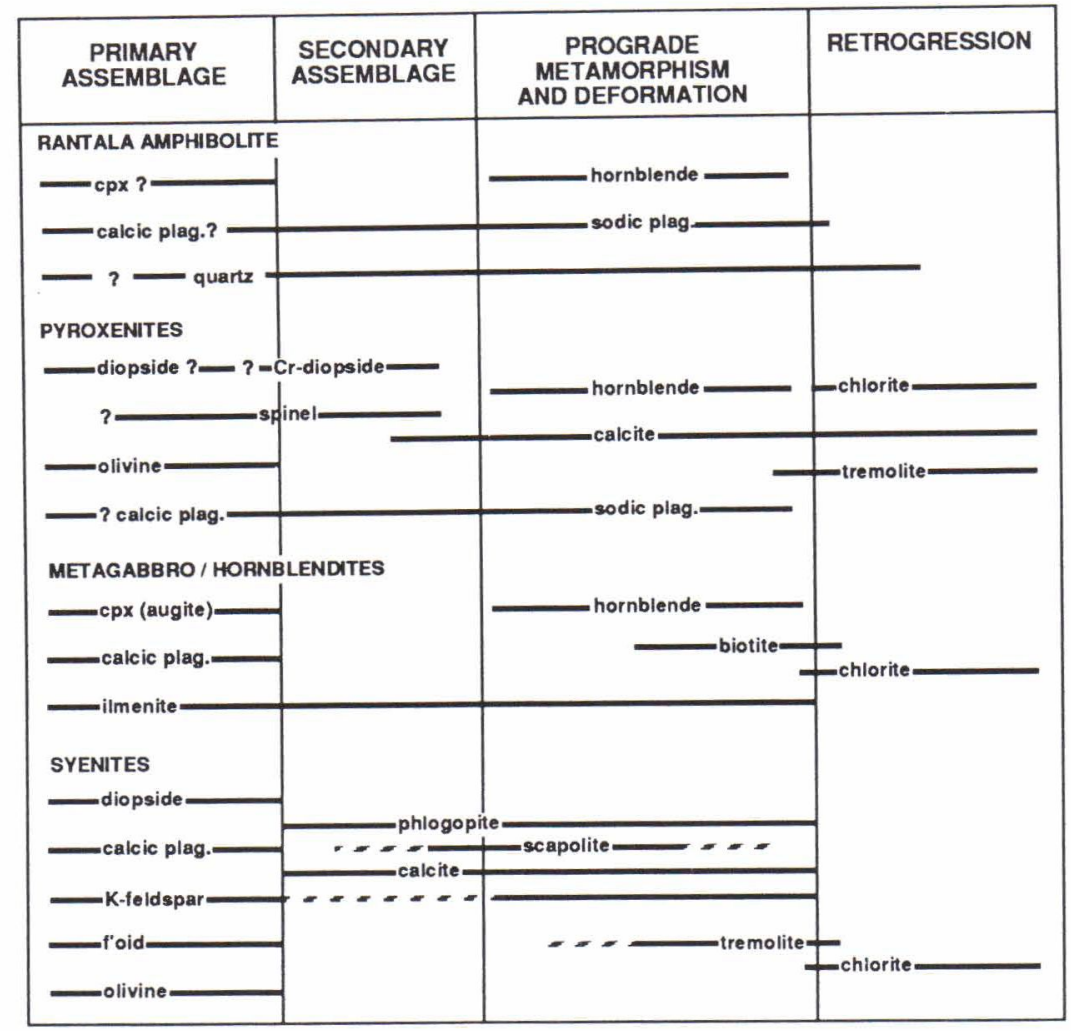

dominates the assemblage, and the plagioclase (always less than $5 \%)$ is usually calcic $\left(\mathrm{An}_{55-75}\right)$. Spinel is a ubiquitous accessory phase, occurring as interstitial chrome spinel (Fig. 2c), or as zincchrome spinel inclusions in diopside (Fig. 2d). Textural and compositional criteria (i.e. low $\mathrm{Cr}$ relics in diopside, high $\mathrm{Cr}$ and $\mathrm{Zn}$ contents of most diopside and the spinel inclusions, evidence of multiple regrowth in plagioclase) suggest this relict assemblage is itself replacing something earlier. Grain size varies from medium to coarse, and cumulate textures involving chrome diopside and chrome spinel survive suggesting a plutonic protolith. Most of this relict assemblage is the high temperature metamorphic assemblage (pretectonic) referred to by Park (1983; see Fig. 3).

b. Hornblende-chlorite schist from diamond drill-core at Suuri Kokkalampi (Fig. 1d). This lithology is gradational into (a.). Field of view $=5 \mathrm{~mm}$ across, crossed nicols.

c. Diopside-spinel pyroxenite with relict cumulate (?) texture, from Louhilampi (Fig. 1d). Intercumulus spinel is a hercynitechromite species with no zinc content. Field of view $=5 \mathrm{~mm}$ across, crossed nicols.

d. Chromian-zinc spinel inclusions in chromian diopside, from a pyroxenite at Louhilampi (Fig. 1d). Field of view $=0.5$ mm across, plane polarized light.

e. Relict diopside-plagioclase-microcline assemblage in syenitic gneiss from Luikonlahti (Fig. 1c). Plagioclase is in extinction position. Field of view $=5 \mathrm{~mm}$ across, crossed nicols.

f. Deformation twin lamellae in diopside from syenitic gneiss at Luikonlahti (Fig. 1c). Field of view $=3 \mathrm{~mm}$ across, crossed nicols.

g. Phlogopite with inter- and intra-granular deformation features. The voids in the delaminating mica flakes are filled by chrysotile-calcite-quartz. From a syenitic gneiss at Luikonlahti (Fig. 1c). Field of view $=1.5 \mathrm{~mm}$ across, plane polarized light. h. Field photograph of small chloritized dyke cutting mafic metavolcanic tuff-breccia, Toivolanmäki (Fig. 1b). 
It appears to be part of the hornfels envelope to the serpentinized ultramafic sills in the Outokumpu assemblage (see Park, 1988a). The extensive outcrops at Louhilampi show gradational contacts with carbonates and calc-silicate skarn. The diopside-spinel-plagioclase assemblage occurs as relict masses in a carbonated, foliated amphibolite, consisting of hornblende and sodic plagioclase $\left(\mathrm{An}_{15-25}\right)$. This secondary assemblage is itself largely replaced by tremolitic amphibole and calcite (Fig. 3).

\section{Syenitic gneiss}

A »diopside syenite» reported by Väyrynen (1939) from Luikonlahti is the largest of these bodies exposed extensively around the Pajamalmi open pit (Luikonlahti mine), and temporarily in road construction work during the summer of 1986 (Fig. 1). This lithology (termed »barren skarn» in Eskelinen et al., 1983, and Park, 1988b) shares the complex and intense deformation seen at the Luikonlahti mine, and at outcrop is an augen or a banded, partly schistose gneiss, with coarse-grained lithons separated by schistose partings. Augen of diopside, diopside and feldspar, or scapolite (Väyrynen 1939) are prominent features on weathered surfaces, and elongation of these augen defines a strong lineation (Park 1988b). Two modal gradations are evident, one in which the "syenitic» parent is progressively carbonated, the other in which the schistose partings progressively dominate the rock leaving only isolated augen of feldspathic material in a coarse phlogopitic schist.

A relict original assemblage, consisting of plagioclase $\left(\mathrm{An}_{40-50}\right)+$ microcline + diopside \pm olivine, is present (Fig. 2e). Modal proportions vary considerably, but are usually plagioclase $>$ diopside $>$ microcline $>$ olivine, and microcline is never more than $5 \%$ of the preserved assemblage (Fig. 3). This assemblage is progressively replaced by a microcline + phlogopitic mica \pm tremolitic amphibole \pm zoisite or clinozoisite \pm scapolite assemblage in which mica and amphibole define a strong schistosity (Fig. 3). Calcite forms an integral part of this assemblage. Sphene is ubiquitous and may locally form up to $10 \%$ of the assemblage, apatite is usually abundant.

In one sample examined in this study a relict assemblage consisting entirely of diopside and serpentinized olivine was found, and it appears to have been originally non-feldspathic. These relics are now embedded in a groundmass of phlogopite with minor tremolite, carbonate and secondary chlorite.

Of all these intrusive rocks, the syenitic gneiss is the most strongly deformed. The primary relics form single grain or mosaic prophyroclasts, the most common being elongate diopside aggregates, in a strongly foliated matrix of phlogopitic mica \pm amphibole. Diopside grains show a variety of internal deformation features such as twin lamellae (Fig. 2f), slip planes and dislocations. Phlogopitic mica defines the schistosity and is itself deformed, displaying a variety of kinkbands, undulose extinction and intracrystalline cataclastic features associated with the growth of quartz, chrysotile, chlorite, and carbonate (Fig. $2 \mathrm{~g}$, cf. Goodwin and Wenk, 1990). Within large lithons, phlogopite forms a static overgrowth on relict assemblages, and relationships with the schistosity suggest it predates deformation in part.

Deformation of the relict assemblage and its recrystallization have largely involved grain-size reduction and sub-grain formation. This is especially true for the diopside grains, with deformed aggregates from single grains still exceeding $5 \mathrm{~mm}$ in diameter. This suggests that the protolith was very coarse grained and truly plutonic rather than hypabyssal.

\section{Chloritized dykes}

These occur at two localities, cutting serpentinite on the southwest shore of Suuri Kokkalampi (Figs. 1, 2h; see Park, 1983, fig. 9), and cutting mafic metavolcanic rocks and serpentinite at Toivalanmäki, $600 \mathrm{~m}$ southwest of Rantala 
farm (Fig. 1; see Park, 1984, fig. 6). The dykes vary from less than $10 \mathrm{~cm}$ thick to $2 \mathrm{~m}$ wide, with the longest being traced for $25 \mathrm{~m}$. All the examples reported are heavily altered, now consisting of chlorite and talc with minor magnetite and ilmenite; zircon is abundant in the Suuri Kokkalampi dyke. The chlorites are a pale clinochlore and a talc-chlorite, which at Suuri Kokkalampi is chromian. At Toivalanmäki, the rock is extremely fine grained, but the Suuri Kokkalampi example varies from medium to extremely coarse grained (books of talc-chlorite may exceed $10 \mathrm{~mm}$ diameter). Replacement of the primary assemblage is complete, with neither mineral relics (apart from zircon) or relict textures being present. The interpretation of these rocks as originally hypabyssal derives entirely from the preserved field relationships. Their completely secondary petrography, consistent with low-temperature alteration, should be contrasted with that described from the sheeted metadiabase complex in the Jormua ophiolite (Kontinen, 1987).

\section{Relationships}

With the exception of the feldspathic pyroxenite mass at Louhilampi and the chloritized dykes, all these bodies have tectonized contacts with other rocks of the Outokumpu assemblage. The Louhilampi pyroxenites have evidently nontectonic contacts against serpentinite, but they are so heavily altered and overprinted that their original nature is obscured.

The chloritized dykes cut both the volcanic rocks and the serpentinites, and are discordant to the contact between these rock types. They are in turn tectonized and carry all the fabrics recognised in their wallrocks. The implication is that any suite of rocks related to these dykes represent a late, but pre-tectonic igneous episode in the evolution of the Outokumpu assemblage. The emplacement of the dykes, post-dates the juxtaposition of the serpentinites and the metavol- canic rocks (itself an apparently intrusive relationship, Park, 1983).

\section{Geochemistry}

Any discussion or interpretation of these rocks that regards them as having been derived from an igneous protolith must be prefaced by two major caveats. Firstly, three of the pyroxenites, one hornblendite, and all but three of the syenites contain at least one phase that makes up more than $45 \%$ of the norm (Tables 1,2). This suggests that most of these rocks are cumulates, and consequently, of limited use in identifying parent magmas. Secondly, recrystallization of these rocks has involved extensive alteration, most notably the addition of water and $\mathrm{CO}_{2}$, and the evident redistribution of silica. Whether or not the bulk composition bears any relationship to the original composition is going to involve some degree of speculation, but this can be constrained by a consideration of relict mineral assemblages. Simply renormalizing analyses to $100 \%$ minus water and $\mathrm{CO}_{2}$ is not a valid procedure, and for that reason Niggli Numbers (molecular norms) and CIPW Norms are used here. It is assumed the »silica», »calcite» and »apatite» $(\mathrm{Q}, \mathrm{cc}, \mathrm{ap}$, $s i, p$ ) in these calculations can account for the products of hydrous alteration involving $\left(\mathrm{CO}_{3}\right)^{2}$ and $\left(\mathrm{PO}_{4}\right)^{2}$-radicals, and silica mobility. This assumption is realistic and consistent with petrographic observations, though it remains an assumption nonetheless.

The behaviour of $\mathrm{Cr}$ is a major problem in any consideration of rocks from the Outokumpu assemblage, and these rocks in particular. $\mathrm{Cr}$ here is usually contained in silicate phases or in spinels of unusual composition (see Treloar, 1987). If "chromite» is included in the CIPW norm calculations the result is large amounts of "chromite» in the norm - up to two orders of magnitude greater than is observed in these rocks. The redistribution of $\mathrm{FeO}$ and $\mathrm{Fe}_{2} \mathrm{O}_{3}$ in $(\mathrm{cm})$ has dramatic effects on the amount of $\mathrm{Di}, \mathrm{Hy}$, and 


\begin{tabular}{|c|c|c|c|c|c|c|c|c|c|c|c|c|c|c|c|c|c|c|c|c|c|c|c|}
\hline & $\mathrm{SiO}_{2}$ & $\mathrm{iO}_{2}$ & $\mathrm{Al}_{2} \mathrm{O}_{3}$ & $\mathrm{Fe}_{2} \mathrm{O}_{3}$ & $\mathrm{FeO}$ & $\mathrm{MnO}$ & $\mathrm{MgO}$ & $\mathrm{CaO}$ & $\mathrm{Na}_{2} \mathrm{O}$ & $\mathrm{K}_{2} \mathrm{O}$ & $\mathrm{P}_{2} \mathrm{O}_{5}$ & $\mathrm{CO}_{2}$ & totals & $\mathrm{Cr}$ & $\mathrm{Ni}$ & $\mathrm{Sr}$ & $\mathrm{Zr}$ & $\mathrm{Y}$ & $\mathrm{La}$ & $\mathrm{Ce}$ & $\mathrm{Ba}$ & $\mathrm{Rb}$ & $\mathrm{Pb}$ \\
\hline \multicolumn{24}{|c|}{ Hornblendite } \\
\hline SK39 & 33.87 & 1.19 & 17.04 & 3.79 & 15.15 & 0.14 & 15.03 & 5.34 & 1.08 & 0.90 & 0.08 & & 93.61 & 589 & 246 & 32 & 67 & 31 & 1 & 50 & 38 & 42 & 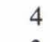 \\
\hline SK2/61 & 38.01 & 8.04 & 12.16 & 3.39 & 13.57 & 0.22 & 10.47 & 10.57 & 1.65 & 0.79 & 0.50 & & 99.37 & 54 & 77 & 126 & 62 & 47 & 7 & 49 & 56 & 15 & 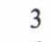 \\
\hline SK3/61 & 34.36 & 7.38 & 12.19 & 3.89 & 15.55 & 0.32 & 8.87 & 8.80 & 1.41 & 0.83 & 0.05 & & 93.65 & 87 & 98 & 90 & 89 & 35 & 9 & 60 & 171 & 15 & 6 \\
\hline \multicolumn{24}{|c|}{ Pyroxenite } \\
\hline LO 8 & 49.34 & 0.16 & 8.74 & & 5.04 & 0.14 & 12.94 & 20.04 & 0.76 & 0.27 & 0.11 & & 97.54 & 5538 & 963 & 106 & 25 & 8 & 1 & 22 & - & 3 & 7 \\
\hline LO 9 & 46.22 & 0.46 & 16.88 & & 4.01 & 0.11 & 11.22 & 15.80 & 0.61 & 0.77 & 0.19 & & 96.27 & 1796 & 515 & 195 & 43 & 15 & 3 & 15 & 91 & 31 & 12 \\
\hline LO 11 & 46.93 & 0.22 & 16.15 & & 2.96 & 0.07 & 11.63 & 15.98 & 0.38 & 0.68 & 0.14 & & 95.14 & 567 & 192 & 196 & 22 & 10 & - & 11 & 42 & 20 & 5 \\
\hline LO 12 & 45.97 & 0.15 & 17.06 & & 4.43 & 0.07 & 11.06 & 15.82 & 0.53 & 0.94 & 0.07 & & 96.10 & 1073 & 285 & 207 & 22 & 1 & - & 10 & 84 & 37 & 5 \\
\hline LO 13 & 47.18 & 0.10 & 6.16 & & 5.64 & 0.18 & 13.58 & 19.97 & 0.59 & 0.20 & 0.04 & & 93.64 & 6308 & 547 & 77 & 13 & 8 & - & 18 & - & 1 & 0 \\
\hline LO 14 & 46.78 & 0.17 & 7.82 & & 6.66 & 0.14 & 16.74 & 16.39 & 0.84 & 0.35 & 0.19 & & 96.08 & 9893 & 1256 & 47 & 13 & 6 & - & 30 & - & 2 & 6 \\
\hline \multicolumn{24}{|c|}{ Rantala amphibolite } \\
\hline LS 101 & 55.02 & 0.66 & 12.72 & & .05 & 7 & 6.96 & 9.24 & 2.22 & 0.20 & 0. & & & 35 & 65 & 72 & 51 & 25 & - & 15 & 28 & - & 3 \\
\hline L & 1.26 & 0.58 & 14.63 & & 10.26 & 0.14 & 7.65 & 11.21 & 2.10 & 0.37 & 0. & & 26 & 177 & 99 & 44 & 40 & 22 & - & 22 & 7 & - & - \\
\hline \multicolumn{24}{|c|}{ Chloritized dykes } \\
\hline LS32 & 34.36 & 0.55 & 18.39 & & .42 & 0.06 & & & & & & & & 1125 & & 13 & & 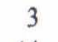 & - & 5 & 1 & - & 1 \\
\hline SK9 & .63 & 0.29 & 3.42 & & .26 & 0.06 & 38.54 & 0.06 & 0 & 0 & 0 & & 36 & 452 & 1443 & 10 & 1296 & 44 & - & 17 & - & - & 1 \\
\hline \multicolumn{24}{|l|}{ Syenite } \\
\hline LK110a & .99 & 1.24 & 18.11 & 0.72 & 1.61 & 0.05 & 11.60 & & & & & & & 577 & 1 & 28 & 91 & 24 & 6 & 1 & 01 & 43 & 7 \\
\hline LK110b & 46.85 & 1.19 & 19.13 & 0.85 & 1.33 & 0.04 & 9.57 & 13.35 & 1.50 & 3.74 & 0.13 & 0.03 & 97.71 & 609 & 298 & 324 & 89 & 32 & 4 & 8 & 261 & 41 & 9 \\
\hline LK112 & 45.71 & 1.17 & 18.55 & 0.76 & 2.66 & 0.08 & 9.35 & 14.92 & 1.34 & 2.95 & 0.16 & 0.00 & 97.65 & 526 & 197 & 251 & 80 & 27 & 2 & 7 & 228 & 38 & 8 \\
\hline LK113 & 45.17 & 1.75 & 18.92 & 0.90 & 1.79 & 0.09 & 10.35 & 12.99 & 0.92 & 3.68 & 0.56 & 0.08 & 97.20 & 434 & 23 & 349 & 120 & 43 & - & 13 & 229 & 49 & 18 \\
\hline LK11a & 46.84 & 1.55 & 21.84 & 0.94 & 1.12 & 0.04 & 6.84 & 10.17 & 0.85 & 5.78 & 0.23 & 0.46 & 96.66 & 530 & 210 & 219 & 98 & 38 & 4 & 11 & 245 & 43 & 13 \\
\hline LK11b & 46.56 & 1.47 & 20.26 & 1.06 & 1.28 & 0.04 & 8.27 & 10.52 & 0.85 & 5.79 & 0.25 & 0.71 & 97.06 & 494 & 201 & 222 & 91 & 34 & 2 & 13 & 247 & 39 & 9 \\
\hline LK12 & 45.96 & 0.78 & 13.72 & 1.49 & 3.42 & 0.15 & 9.05 & 22.05 & 0.90 & 0.89 & 0.12 & 0.00 & 98.53 & 494 & 201 & 222 & 91 & 34 & 2 & 13 & 247 & 39 & 9 \\
\hline LK13 & 45.48 & 0.93 & 16.55 & 1.75 & 6.32 & 0.11 & 13.59 & 3.33 & 1.76 & 6.38 & 0.06 & 0.15 & 96.41 & 162 & 213 & 112 & 60 & 23 & 3 & 5 & 378 & 85 & 4 \\
\hline LK14 & 43.81 & 1.98 & 22.44 & 1.14 & 1.73 & 0.04 & 8.37 & 10.08 & 2.06 & 4.62 & 0.71 & 0.00 & 96.98 & 491 & 277 & 387 & 140 & 36 & 6 & 8 & 265 & 60 & 18 \\
\hline LK15 & 44.54 & 1.29 & 17.92 & 1.27 & 2.63 & 0.12 & 10.47 & 12.67 & 1.57 & 3.34 & 0.22 & 1.56 & 97.60 & 459 & 145 & 279 & 92 & 32 & - & 11 & 159 & 34 & 6 \\
\hline LK16 & 40.15 & 1.26 & 18.28 & 1.91 & 1.93 & 0.04 & 11.28 & 13.98 & 0.70 & 3.93 & 0.24 & 3.12 & 96.82 & 475 & 143 & 331 & 97 & 30 & - & 10 & 190 & 40 & 7 \\
\hline LK 17 & 35.18 & 0.97 & 16.59 & 2.17 & 2.45 & 0.12 & 10.56 & 18.03 & 0.21 & 3.60 & 0.11 & 6.09 & 96.08 & 416 & 86 & 298 & 74 & 21 & 4 & 3 & 168 & 32 & 2 \\
\hline LK18 & 50.54 & 1.49 & 14.81 & 1.98 & 9.57 & 0.25 & 10.08 & 6.61 & 2.87 & 0.13 & 0.13 & 0.45 & 98.91 & 183 & 85 & 144 & 98 & 26 & 14 & 24 & 48 & 3 & 13 \\
\hline LK19 & 50.65 & 1.48 & 15.24 & 2.54 & 8.88 & 0.26 & 9.42 & 6.54 & 3.16 & 0.16 & 0.13 & 0.03 & 98.49 & 191 & 86 & 145 & 96 & 27 & 9 & 21 & 61 & 3 & 11 \\
\hline
\end{tabular}

(In the pyroxenite, chloritized dykes and Rantala amphibolite, $\mathrm{FeO}$ is total $\mathrm{Fe}$.)

Whole rock chemical analyses were carried out on fused borosilicate glass beads (major elements) and pressed resin-powder pellets (trace elements) using the XRF facilities (Philips PW1450) at the Department of Geology and Applied Geology, University of Glasgow, Scotland. Spectrum analysis was carried out by the Compton scattering method (see Harvey \& Atkins, 1982). 
Table 2. CIPW norms for the metagabbros and related rocks in the Outokumpu assemblage.

\begin{tabular}{|c|c|c|c|c|c|c|c|c|c|c|c|c|c|c|c|c|c|c|c|c|c|}
\hline & Q & $\mathrm{C}$ & or & $a b$ & an & lc & ne & $\mathrm{Di}$ & Hy & $\mathrm{Ol}$ & fo & $\mathrm{fa}$ & $\mathrm{cs}$ & $\mathrm{mt}$ & il & $\mathrm{hm}$ & $\mathrm{pf}$ & $\mathrm{ru}$ & ap & $\mathrm{cc}$ & total \\
\hline \multicolumn{22}{|c|}{ Hornblendite } \\
\hline SK $14 / 39$ & & 4.77 & 5.32 & 1.48 & 25.97 & & 4.15 & & & 43.98 & 26.23 & 17.75 & & 5.50 & 2.26 & & & & 0.19 & & 93.61 \\
\hline SK 2/61 & & & 4.67 & 7.45 & 23.45 & & 3.53 & 20.64 & & 18.29 & 13.15 & 5.14 & & 4.92 & 15.27 & & & & 1.16 & & 99.38 \\
\hline SK 3/61 & & & 4.90 & 4.42 & 24.49 & & 4.07 & 15.35 & & 20.65 & 12.25 & 8.40 & & 5.64 & 14.02 & & & & 0.12 & & 93.65 \\
\hline \multicolumn{22}{|l|}{ Pyroxenite } \\
\hline LO 8 & & 1.60 & 2.15 & 19.64 & & 2.32 & 63.15 & & 8.13 & 6.17 & 1.95 & & & 0.30 & & & & & 0.26 & & 97.54 \\
\hline LO 9 & & 4.55 & 5.16 & 42.05 & & & 28.73 & 1.36 & 14.10 & 11.12 & 2.99 & & & 0.87 & & & & & 0.44 & & 96.27 \\
\hline LO 11 & & & 4.02 & 3.22 & 40.36 & & & 30.10 & 8.74 & 7.97 & 6.65 & 1.32 & & & 0.42 & & & & 0.33 & & 95.14 \\
\hline LO 12 & & & 5.55 & 3.33 & 41.40 & & 0.62 & 29.26 & & 15.48 & 11.72 & 3.76 & & & 0.28 & & & & 0.16 & & 96.10 \\
\hline LO 13 & & & & & 13.57 & 0.93 & 2.70 & 66.47 & & 9.02 & 6.71 & 2.30 & 0.67 & & 0.19 & & & & 0.09 & & 93.64 \\
\hline LO 14 & & & 2.07 & 1.81 & 16.54 & & 2.87 & 50.77 & & 21.26 & 16.07 & 5.19 & & & 0.32 & & & & 0.44 & & 96.08 \\
\hline \multicolumn{22}{|c|}{ Rantala amphibolite } \\
\hline LS 101 & 7.05 & & 1.18 & 18.78 & 24.16 & & & 17.69 & 28.05 & & & & & 1.25 & 0.14 & & & & & & 98.30 \\
\hline LS 102 & & & 2.19 & 17.77 & 29.41 & & & 21.32 & 25.46 & 0.88 & 0.43 & 0.45 & & 1.10 & 0.14 & & & & & & 98.26 \\
\hline \multicolumn{22}{|l|}{ Syenite } \\
\hline LK011a & & & 18.26 & 0.92 & 35.32 & 4.59 & & 25.61 & & 6.49 & 0.03 & 6.46 & & 1.04 & 2.36 & 0.70 & 0.68 & & & & 95.96 \\
\hline LK0110b & & & 11.25 & & 34.43 & 8.51 & 6.88 & 23.95 & & 8.92 & 8.92 & & & 0.97 & 2.26 & 0.18 & & 0.30 & & 0.07 & 97.71 \\
\hline LK0112 & & & 2.48 & & 35.90 & 11.72 & 6.14 & 29.18 & & 8.54 & 7.64 & 0.89 & & 1.10 & 2.22 & & & 0.37 & & & 97.65 \\
\hline LK0113 & & & 12.96 & & 36.64 & 6.89 & 4.22 & 18.40 & & 12.08 & 12.08 & & & 0.99 & 3.32 & 0.22 & & 1.30 & & 0.18 & 97.21 \\
\hline LK011a & & & 30.30 & & 38.72 & 3.03 & 3.90 & 5.00 & & 10.31 & 10.31 & & & & 2.45 & 0.94 & 0.44 & 0.53 & & 1.05 & 96.66 \\
\hline LK011b & & & 24.73 & & 34.38 & 7.44 & 3.90 & 9.10 & & 11.48 & 11.48 & & & & 2.79 & 1.06 & 0.00 & 0.58 & & 1.61 & 97.06 \\
\hline LK012 & & & & & 30.77 & 4.12 & 4.13 & 46.14 & & 3.39 & 2.83 & 0.56 & 6.06 & 2.16 & 1.48 & & & 0.28 & & & 98.53 \\
\hline LK013 & & 1.19 & 32.86 & & 15.18 & 3.80 & 8.07 & & & 30.53 & 23.72 & 6.82 & & 2.54 & 1.77 & & & 0.14 & & 0.34 & 96.41 \\
\hline LK014 & & & 13.72 & & 38.35 & 10.65 & 9.44 & 5.43 & & 12.84 & 12.84 & & & & & 3.74 & 1.14 & 0.02 & 1.65 & & 96.99 \\
\hline LK015 & & & 19.74 & 0.71 & 31.99 & & 6.81 & 15.34 & & 14.66 & 13.58 & 1.08 & & 1.84 & 2.45 & & & 0.51 & & 3.55 & 97.60 \\
\hline LK016 & & & 4.60 & & 35.14 & 14.60 & 3.21 & 10.06 & & 16.42 & 16.42 & & & 2.70 & 2.39 & 0.05 & & 0.56 & & 7.10 & 96.82 \\
\hline LK017 & & & & & 33.70 & 16.68 & 0.96 & 3.89 & & 18.18 & 17.22 & 0.96 & 3.58 & 3.15 & 1.84 & & & 0.26 & & 13.85 & 96.08 \\
\hline LK018 & & & 0.77 & 24.28 & 27.15 & & & 1.58 & 37.64 & 0.46 & 0.29 & 0.17 & & 2.87 & 2.83 & & & 0.30 & & 1.02 & 98.91 \\
\hline LK019 & & & 0.95 & 26.74 & 26.93 & & & 3.62 & 31.90 & 1.48 & 0.94 & 0.54 & & 3.68 & 2.81 & & & 0.30 & & 0.07 & 98.49 \\
\hline
\end{tabular}




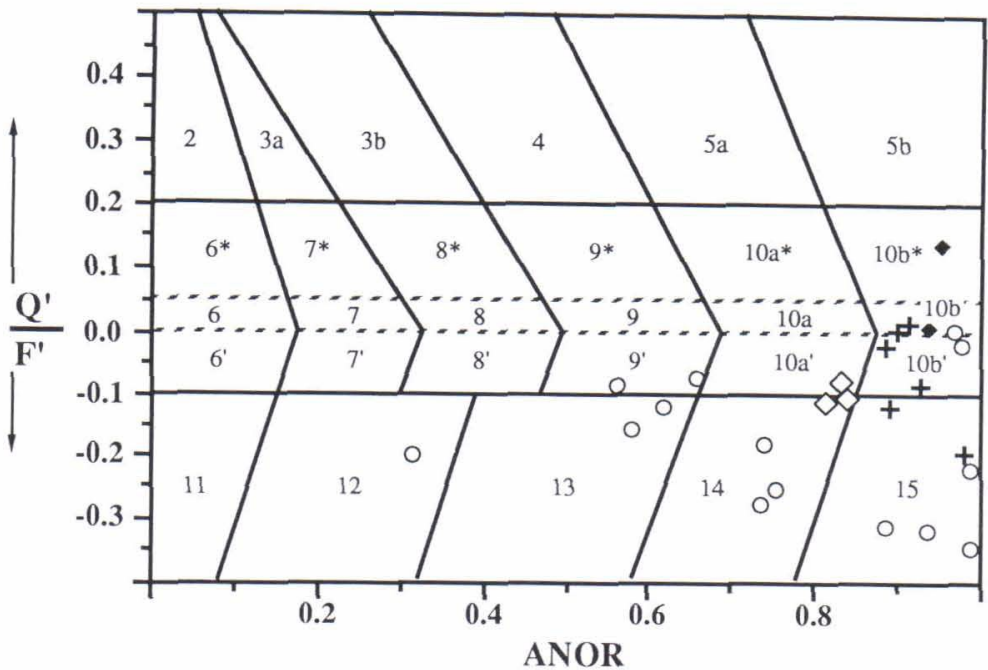

$\mathrm{ANOR}=\mathrm{an} /($ or + an $)$

$Q^{\prime}=Q /(Q+o r+a b+a n)$

$F^{\prime}=(n e+l c+k p) /(n e+l c+k p+o r+a b+a n)$ $\diamond$ Rantala amphibolite

- hornblendite

+ pyroxenite

o syenite
Fig. 4. CIPW nomenclature and classification of the metagabbros and related rocks from the Outokumpu assemblage, ANOR vs. Q' plot after Streckeisen and LeMaitre (1979). Field names: 2. alkali-feldspar granite; 3a, 3 b. granite; 4 . granodiorite; $5 a, 5 b$. tonalite; 6. alkali-feldspar syenite; 7. syenite; 8. monzonite; 9. monzodiorite/monzogabbro; 10a, 10b. diorite/gabbro; 11 . foid syenite; 12 . foid monzosyenite; 13. foid monzodiorite/ monzogabbro; 14 . foid diorite/gabbro; 15 . foidolite. ${ }^{*}$ indicates prefix "quartz-», 'indicates prefix »foidbearing». Data from Tables 1 and 2 .
$\mathrm{Ol}$ in the norm, producing a normative analysis that bears little or no relationship to the relict mineral assemblages. Relict chromite cumulates are rare in the Outokumpu assemblage and have only recently been described from serpentinites in the assemblage (Vuollo and Piirainen, 1989). For these reasons »chromite» or $» \mathrm{~cm}$ » has been left out of the norm calculations.

The pyroxenites present an additional difficulty, in that these rocks most closely resemble the chromium-rich calc silicate skarns that are such an abundant and distinctive lithology in the $\mathrm{Ou}$ tokumpu assemblage. This similarity is only superficial. Though the pyroxenites have a $\mathrm{Cr}$ content that is high for igneous rocks that are not ultramafic, such concentrations are not unusual in cumulates containing chrome spinel or chrome-diopside. Critically, the pyroxenites are feldspar-bearing, whereas one of the diagnostic characteristics of the chromium-rich calc-silicate skarns is that they are feldspar-free (Huhma, 1971; all Cr-rich calc-silicate skarns contain $<2.0$ wt $\% \mathrm{Al}_{2} \mathrm{O}_{3}$, most contain $<0.5 \mathrm{wt} \%$ ). Further- more, the pyroxenites contain relict mineral assemblages and textures indicative of an igneous protolith, and the more feldspathic members of the group closely resemble the more mafic syenitic gneiss.

Using the CIPW norm classification scheme of Streckeisen and LeMaitre (1979), the major element chemistry of these rocks suggests a number of protolith affinities that are in part, consistent with the petrology of the relict assemblages of these rocks, where these exist (Fig. 4). The Rantala amphibolite plots here as a dolerite (in the monzogabbro - monzodiorite field), and is the only rock that consistently plots in the saturated fields. With the exception of one pyroxenite sample, and two syenite samples, all other analyzed rocks fall into the undersaturated feldspathoid-bearing fields. Being dominated by hornblende, ilmenite and chlorite, the hornblendites position on this diagram means very little. Of the pyroxenites, all but one fall in the feldspathoid-bearing gabbro field, while the syenites, with one exception, define a broad trend 


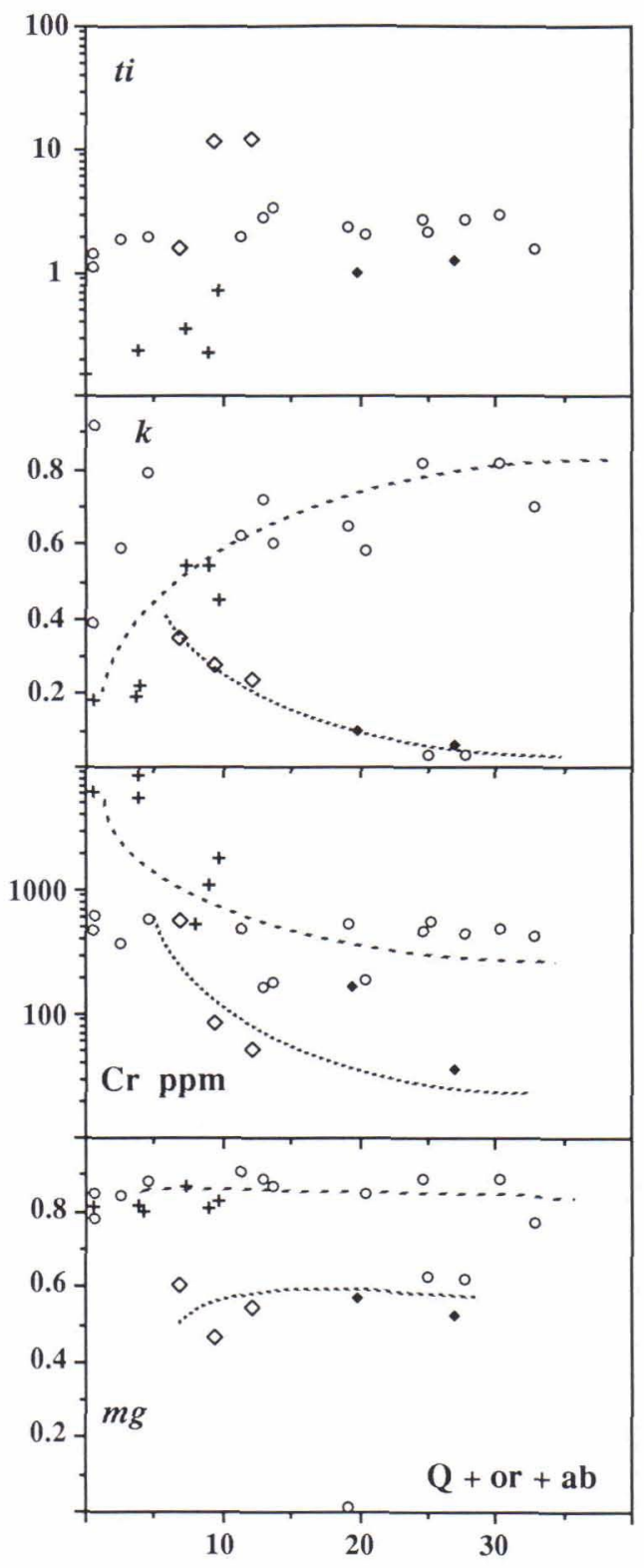

- Rantala amphibolite

$\diamond$ hornblendite

+ pyroxenite

- syenite

Fig. 5. Plots of Niggli, $t i, k$, and $m g$, plus $\mathrm{Cr}$, against differentiation index $(\mathrm{Q}+$ or $+\mathrm{ab})$ for the metagabbros and related rocks of the Outokumpu assemblage; data from Tables 1 and 2. Trends indicated on this and subsequent figures are proposed rather than demonstrated or modelled. from feldspathoid-bearing monzodiorite to feldspathoidolite. Most compositions are consistent with the older terms »essexite» or "theralite».

Among the syenites an inverse relationship is apparent between calcium content (ANOR) and silica content (Q' and F'). As calcite (cc) was included in the norm calculations (and is therefore excluded from the calculations behind this plot) this cannot be attributed to modal dilution during the addition of carbonate. What is not apparent on this diagram is any trend connecting the various petrographic groups.

In the plots involving differentiation parameters two trends are consistently apparent. One contains all the pyroxenites and most of the syenites, the other contains the hornblendites and the Rantala amphibolite. These two trends are apparent on the Niggli $k$ v. D.I. and $m g$ v. D.I. plots, and are present, but less apparent on the Niggli $t i$ v. D.I. and $\mathrm{Cr}$ ppm v. D.I. plots (where D.I. is Differentiation Index, Fig. 5). Similar trends are also evident on the Niggli $t i \mathrm{v} . m g$ and $m g$ v. $k$ plots (Fig. 6). Significantly, the trends are apparent when differentiation factors such as $\mathrm{Q}+$ or $+\mathrm{ab}$ or Niggli $m g$ are used, but are not seen when Niggli $s i$ is so employed, indicating some degree of silica alteration. Two syenite samples consistently fall away from the trend marked by all the other syenite samples. These samples are a diopside-plagioclase rock containing neither phlogopite or microcline, and fall within the general area of the pyroxenites on the $m g \mathrm{v} . k$ plot (Fig. 5). Similar differentiation patterns are seen on the $\mathrm{Y}$ v. $\mathrm{Zr}, \mathrm{Ti}$ v. $\mathrm{Zr}, \mathrm{Y}$ v. $\mathrm{Cr}$ and Ti v. Cr plots (Fig. 7), though the chloritized dykes are erratic in their behavior under these parameters.

What these plots illustrate well, is that the starting protolith was igneous, and that the trend towards undersaturation with increased alkalis and $\mathrm{Ca}$ is a real igneous trend. The undersaturation of the syenites is not a feature related to carbonate-metasomatism, and the presence of leucite and nepheline in the norm reflects the presence of some feldspathoid in the original rock. This need not have been the rather unusual 

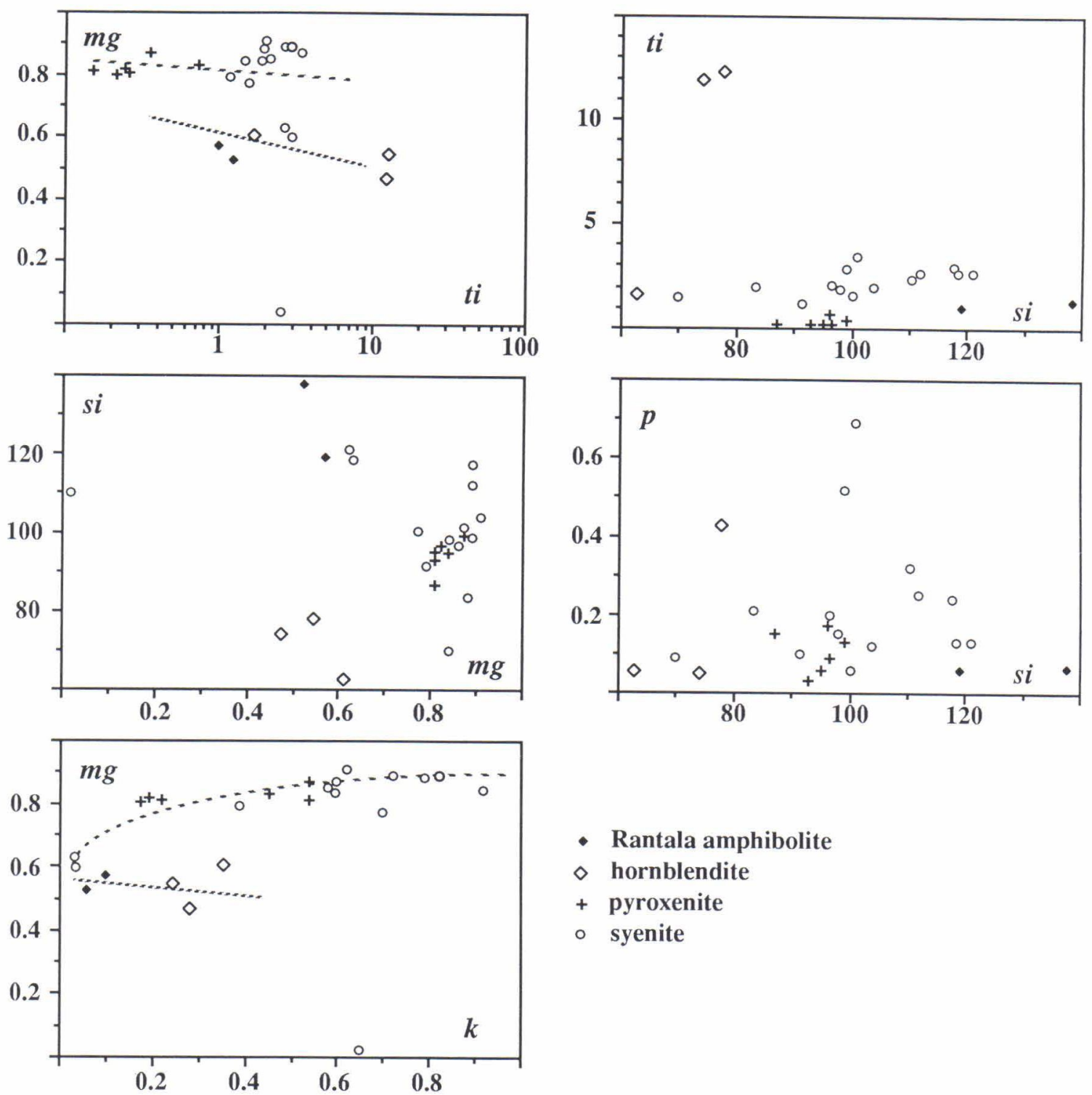

- Rantala amphibolite

$\diamond$ hornblendite

+ pyroxenite

- syenite

Fig. 6. Niggli vs Niggli parameters for the metagabbros and related rocks of the Outokumpu assemblage. 


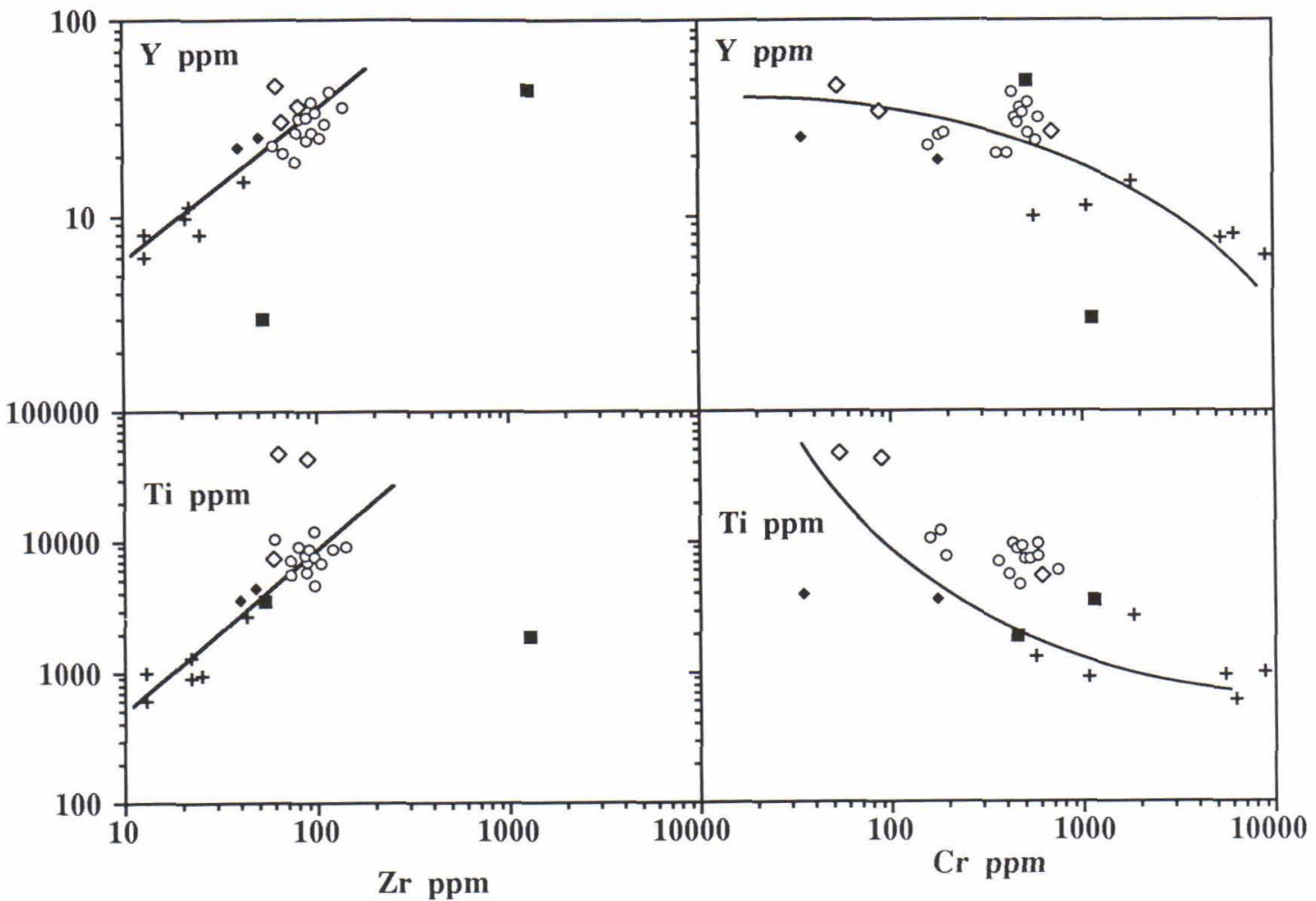

- Rantala amphibolite

$\diamond$ hornblendite

+ pyroxenite

- syenite

- chloritized dykes

Fig. 7. Selected trace elements plots for the metagabbros and related rocks of the Outokumpu assemblage (data from Tables 1 and 2).

combination of nepheline and leucite, but perhaps potassic nepheline, pseudoleucite, kalsilite or analcite. The hornblendites represent a more fractionated relative of the Rantala amphibolite, itself related to the metavolcanic rocks of the Outokumpu assemblage (Park 1984, 1988). The pyroxenites and syenites appear to represent a separate igneous clan entirely, viz. one that is consistently undersaturated, but not consistently peralkaline.

\section{Petrogenesis of the syenites and pyroxenites}

The evidence for phlogopitization and carbonation having occurred between intrusion and deformation raises the question of whether this was a magmatic process or some sort of reaction between the primary magma and its host (e.g. the dolomitic carbonate metasediments in the Outokumpu assemblage). Bulk reaction with the primary assemblages described to produce phlogo- 

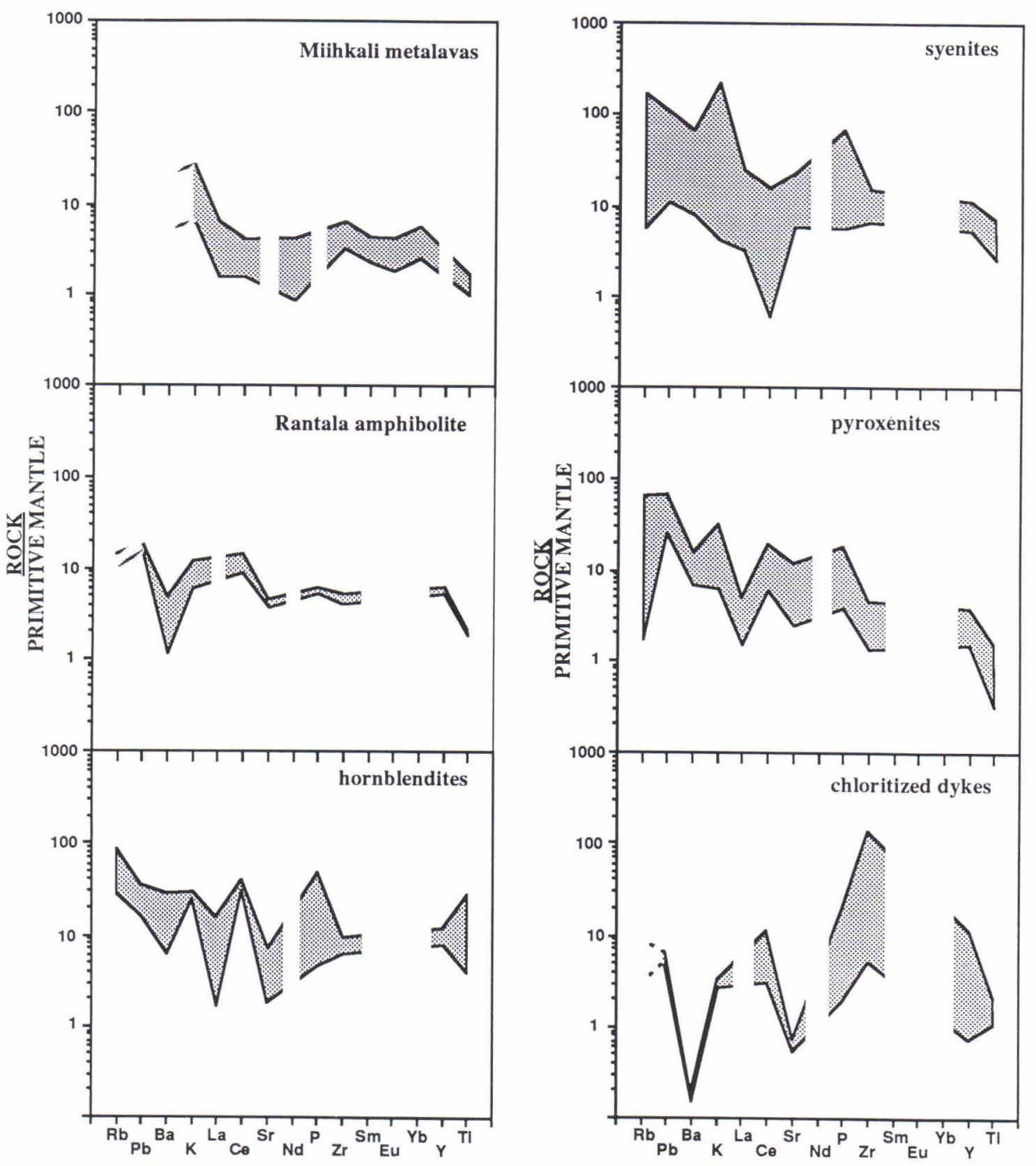

Fig. 8a. Spider diagrams for incompatible elements in metagabbro and related rocks in the Outokumpu assemblage, compared with the Miihkali metalavas. 


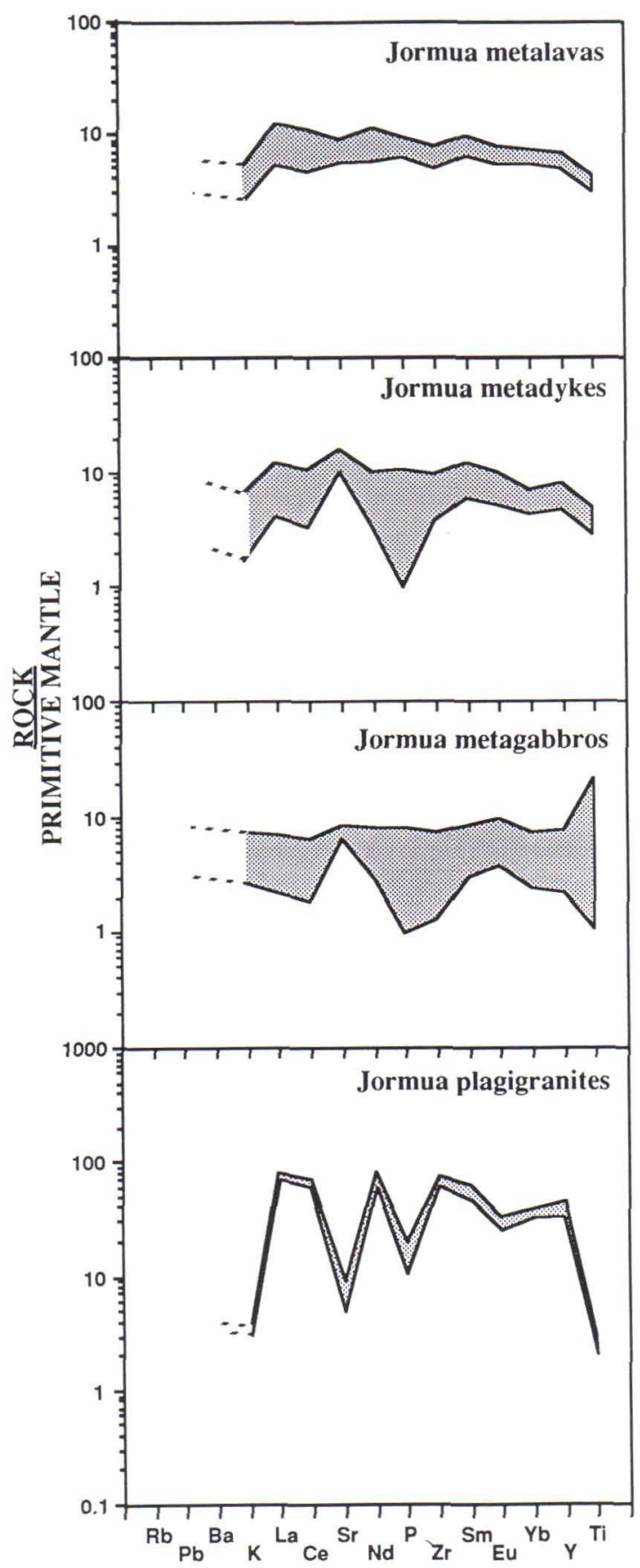

Fig. 8b. Spider diagrams for incompatibe elements in the metalavas, metadykes, metagabbros and plagigranites from the Jormua mafic-ultramafic complex (ophiolite). Element concentrations normalized to primitive mantle abundances after Hofmann (1988, except P, from Sun, 1980). Data for the Miihkali metalavas are from Rehtijärvi and Saastamoi- pite and calcite can be summarized by reactions of the form:

$$
\begin{aligned}
& \text { (reaction 1) } \mathrm{KAlSi}_{3} \mathrm{O}_{8}+\mathrm{KAlSiO}_{4}+\mathrm{KAlSi}_{2} \mathrm{O}_{6} \\
& \mathrm{k} \text {-spar nepheline leucite } \\
& +9 \mathrm{CaMgSi}_{2} \mathrm{O}_{6}+9 \mathrm{CO}_{2}+3 \mathrm{H}_{2} \mathrm{O} \\
& \text { diopside } \\
& =3 \mathrm{KMg}_{3} \mathrm{AlSi}_{3} \mathrm{O}_{10}(\mathrm{OH})_{2} \\
& \text { phlogopite } \\
& +9 \mathrm{CaCO}_{3}+15 \mathrm{SiO}_{2} \\
& \text { calcite silica }
\end{aligned}
$$

and:

$$
\begin{aligned}
& \text { (reaction 2) } \quad 18 \mathrm{SiO}_{2}+\mathrm{NaAlSiO}_{4}+8 \mathrm{Mg}_{2} \mathrm{SiO}_{4} \\
& \text { silica nepheline olivine } \\
& +4 \mathrm{CaMgSi}_{2} \mathrm{O}_{6}+4 \mathrm{CaCO}_{3}+4 \mathrm{H}_{2} \mathrm{O} \\
& \text { diopside calcite } \\
& =4 \mathrm{Ca}_{2} \mathrm{Mg}_{5} \mathrm{Si}_{8} \mathrm{O}_{22}(\mathrm{OH})_{2} \\
& \text { tremolite } \\
& +\mathrm{NaAlSi}_{3} \mathrm{O}_{8}+4 \mathrm{CO}_{2} \\
& \text { alb. in plag. }
\end{aligned}
$$

probably coincident with:

$$
\begin{aligned}
& \text { (reaction 3) } \mathrm{NaAlSiO}_{4}+3 \mathrm{CaAl}_{2} \mathrm{Si}_{2} \mathrm{O}_{8} \\
& \text { nepheline an. in plag. } \\
& \begin{array}{l}
+\underset{\text { silica }}{2 \mathrm{SiO}_{2}+\mathrm{CO}_{2}} \\
=\underset{\text { scapolite }}{\mathrm{Ca}_{4} \mathrm{Al}_{6} \mathrm{Si}_{6} \mathrm{O}_{24} \mathrm{CO}_{3}}+\underset{\text { alb. in plag. }}{\mathrm{NaAlSi}_{3} \mathrm{O}_{8}}
\end{array}
\end{aligned}
$$

For a parent in which $\mathrm{K}$-feldspar and diopside were more abundant than feldspathoids, such reactions would be limited by the availability of the feldspathoids. This is consistent with the absence of these phases in the mode.

Though these reactions suggest bulk addition of $\mathrm{CO}_{2}$ to the parent intrusion, assimilation of the dolomitic metasediments of the Outokumpu assemblage by a gabbroic or essexitic magma to produce the basic mafic syenites and pyroxenites is not tenable for a number of reasons. The $\mathrm{Ca}$

nen (1985), and for the Jormua complex are from Kontinen (1987); other data is from Table 1. 
content of the whole rock is reflected in the relict feldspar compositions, such that carbonation can be explained adequately by the introduction of $\mathrm{CO}_{2}$ alone (possibly from carbonates in the country rocks). Bulk assimilation of the dolomitic metasediments is also precluded by the trace element data: the high $\mathrm{Cr}$ content of the dolomitic metasediments (between 6000 and 20000 ppm $\mathrm{Cr}$ ) is not reflected in the syenites, nor are the high $\mathrm{Zn}$ and $\mathrm{Cu}$ levels (in metadolomites $\mathrm{Zn}=$ $100-600 \mathrm{ppm}, \mathrm{Cu}=50-800 \mathrm{ppm}$; in the syenites $\mathrm{Zn}=50-200 \mathrm{ppm}, \mathrm{Cu}=5-150 \mathrm{ppm}$; in the pyroxenites $\mathrm{Zn}=100-500 \mathrm{ppm}, \mathrm{Cu}=20-70$ ppm; in the hornblendites $\mathrm{Zn}=50-150 \mathrm{ppm}$, $\mathrm{Cu}=5-20 \mathrm{ppm})$.

Phlogopitization of mafic phases like olivine and diopside is a common characteristic of alkaline intrusions (cf. Puustinen, 1971; and review by Borodin and Pavlenko, 1974; and is distinct from what is commonly regarded as fenitization, see Le Bas, 1987), though common characteristics are evident. Alkali metasomatism (fenitization) cannot be ruled out, and given the abundance of apatite, is even probable, but as an explanation of the high $\mathrm{K}$ and $\mathrm{Na}$ content, or as a precursor to the phlogopitization it is not a necessary processes, nor do the trace element concentrations reflect it having occurred (no abnormal Zr, Y, P, La, Ce concentrations, cf. Le Bas 1987); indeed only the chloritized dykes show any evidence of such abnormal concentrations.

Lack of evidence for bulk assimilation of carbonates in general, and the local dolomitic metasediments in particular, suggests that phlogopitization and carbonation were late stage magmatic events (possibly involving some volatile exchange with the country rocks). However, the high $\mathrm{Na}, \mathrm{K}$ and $\mathrm{Ca}$ levels seen here, appear to be a primary magmatic characteristic of these rocks.

The high $\mathrm{Na}, \mathrm{K}$ and $\mathrm{Ca}$ concentrations in the syenites and pyroxenites are unusual, and bear directly on any attempt to make comparisons with undeformed syenitic rocks elsewhere. Similar rocks described from central and eastern Fin- land (i.e. alkaline orthogneisses with igneous relics, cf. Eskola and Sahama 1930; Marmo et al. 1966) are invariably more sodic, with relict sodic and soda-potassic phases such as aegirine, alkali amphibole, nepheline, astrophyllite and catapleiite. Aside from diopside, and pseudomorphs after olivine, no relict mafic phases are preserved in these rocks, largely due to the extensive growth of phlogopite. Though critically, the absence of aegerine (ac) in the CIPW norms for all these rocks, suggests that the relict mafic assemblages (diopside \pm olivine \pm ? pholopite?) are representative of the original (i.e. predeformation) mafic components.

Chemically, and in their norm composition, the syenites and pyroxenites of the Outokumpu assemblage resemble some syenites that have been related to shonkinites or shoshonites that are otherwise deformed and both sodic and potassic (cf. Norra Kärr complex, southern Sweden, Koark 1969; Shonkin Sag laccolith, Montana, USA, Nash and Wilkinson 1970, 1971; Mordor Complex, central Australia, Langworthy and Black 1978; Loch Borralan and Lochailsh intrusive complexes, N.W. Scotland, Sutherland 1982). Crucial to this comparison with shoshonites and shonkinite are high levels of $\mathrm{Na}$, $\mathrm{K}\left(\mathrm{K}_{2} \mathrm{O}: \mathrm{Na}_{2} \mathrm{O}\right.$ usually $\left.>1\right)$ and $\mathrm{Ca}$ producing a rock that is both an and or normative, usually $n e$ normative, and occasionally $l c$ normative (i.e., it is undersaturated, but not consistently peralkaline). It should be pointed out as well, that the rocks from the Outokumpu assemblage generally have higher $\mathrm{CaO}$ and $\mathrm{Al}_{2} \mathrm{O}_{3}$ contents, and consequently higher an components and modal plagioclase than true shonkinites. Likewise the $\mathrm{La}$ and Ce levels are low compared to most alkaline and peralkaline rocks, and serve to distinguish these rocks from type shonkinites (cf. Nash and Wilkinson, 1970, 1971).

Incompatible element distribution patterns for these rocks are presented as primitive mantle normalized spider diagrams (Fig. 8). These emphasize the subdivision into two distinct suites consisting of the amphibolites and metagabbros on 


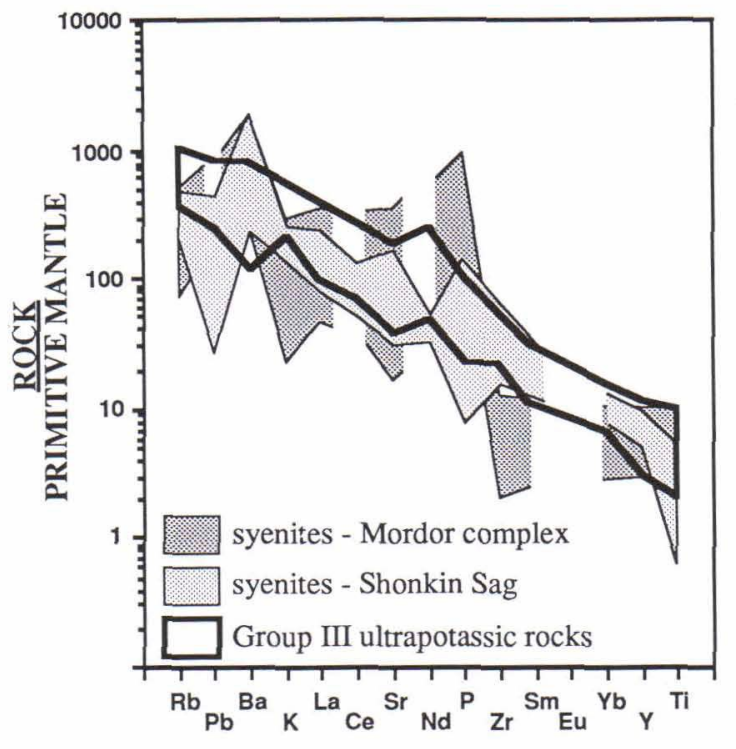

Fig. 9. Spider diagrams for primitive mantle normalized incompatible elements in shonkinites (syenites) from the Mordor Complex, central Australia (data from Langworthy and Black, 1978) and syenites from the Shonkin Sag laccolith, Montana (data from Nash and Wilkinson, 1970, 1971). Outline of data for Group III ultrapotassic rocks is included for comparison (after Foley et al., 1987). Normalization uses same values as Figure 8.

the one hand, the syenites and pyroxenites on the other. For comparative purposes, data from the Miihkali metabasites are included here, as these rocks appear to be the least altered representatives of the volcanic component of the Outokumpu assemblage (data from Rehtijärvi and Saastamoinen, 1985; see discussion in Park, 1988a).

The Rantala amphibolite falls within the range of composition for the Miihkali metalavas, consistent with the interpretation of this rock as representing a minor intrusion related to this volcanism. The hornblendites (metagabbro) are feasibly differentiates (cumulates?) from the same magma (i.e. a parent magma with a flat pattern at c. $10 \mathrm{X}$ primitive mantle resembling midocean ridge basalt). In the absence of direct evidence for intrusive relationships, an affinity with the early volcanism in the Outokumpu assemblage is proposed here.
The syenites and pyroxenites are also broadly similar to each other, but the slope of their incompatible element patterns here (Fig. 8), from as high as $100 \mathrm{X}$ primitive mantle levels for the alkali LIL elements, to $1 \pm 5 \mathrm{X}$ primitive mantle levels for $\mathrm{Y}$ and $\mathrm{Ti}$ contrasts markedly with the amphibolites and metagabbro. The pattern for the chloritized dykes really only emphasizes their extremely altered state, though the broad overlap with the syenites and pyroxenites among the elements $\mathrm{Zr}$ through $\mathrm{Ti}$ may be significant.

The comparison with the shonkinitic syenites of the Mt. Mordor complex and the Shonkin Sag intrusion is made here, using primitive mantle normalized incompatible element spider diagrams (Fig. 9). Though the extreme fractionation giving rise to LIL levels of $>1000 \mathrm{X}$ primitive mantle are not apparent in these rocks, these examples from the Outokumpu assemblage are broadly comparable with the less fractionated members of both intrusive suites. As a group, the syenites and pyroxenites appear to represent the more differentiated shoshonitic members of a calcalkaline suite while the most peralkaline (with normative ne and $l c$ ) approach shonkinitic compositions (similar to the Group III ultrapotassic rocks of Foley et al. 1987). There remain significant differences, most obviously these rocks lack the elevated light rare earth element and $\mathrm{Ba}$ contents of true shonkinites, but their evolved calcalkaline affinities are clear.

\section{Conclusions and discussion}

The Outokumpu assemblage contains two groups of minor intrusions, one of which (amphibolites and metagabbros) appears to be related to the mafic volcanic component of the Outokumpu assemblage. Members of the other group (syenites and pyroxenites) are alkaline and shoshonitic, with the less calcic members being shonkinitic. All tectonic models for the origin of the Outokumpu assemblage must accommodate these new data. 
Comparisons with shoshonites and the Group III ultrapotassic suite of Foley et al (1987; Fig. 9) raises the question of the original tectonic setting for these rocks (cf. Corriveau, 1990): a particularly moot point given the varied interpretations offered for the Outokumpu assemblage (cf. Park, 1988a: Gaál, 1990). Shoshonites and Group III ultrapotassic rocks have a spatial relationship with subduction zones, as oppose to the Group I post-orogenic, or Group II rift-related types. This is consistent with suggestions that shonkinites represent extremely evolved members of the "shoshonite» trend (see for instance Thirlwall and Burnard, 1990) and are therefore of calc-alkaline affinity.

In the type area (NW USA) such subduction has occurred beneath an older continental slab, but for the Outokumpu assemblage, such an analogy does not work. The Outokumpu assemblage contains island-arc and calc-alkaline basalts, but isotopic evidence rules out the presence of crust significantly older than $2.0 \mathrm{Ga}$, either within, or providing a source area, for the rocks of the Outokumpu nappe (cf. Vaasjoki 1981; Huhma, 1986, 1987). This need not be a problem, for instance, Corriveau (1990) recognizes similar rocks in a similar association with relatively juvenile crust in the Elzevier terrane of the Grenville province (eastern Canada), while stressing analogies with one of the Group III type areas: the eastern Sunda arc in Indonesia.

Direct comparison of these rocks and their geochemical tends with the local ophiolite suite (Fig. 8, the Jormua complex, cf. Kontinen, 1987) serves to emphasize these differences. The Jormua data set defines mafic lavas and dykes whose composition (Fig. 8) is truly mid-ocean ridge basalt. The metagabbros are more fractionated, and the trondhjemites (plagigranites) the most fractionated members of a trend. This trend involves progressive enrichment in $\mathrm{Na}$ and depletion in $\mathrm{Ca}$ and $\mathrm{K}$, coupled with increasing silica content. The incompatible trace element spider diagrams depict patterns that are typically »ophiolitic» (see Kontinen, 1987 and Park, 1988a for full discus- sion). If the Miihkali metalavas, amphibolite/ metagabbro, pyroxenites and syenites are likewise treated as members of a contiguous suite, the trend exhibited is distinctively calc-alkaline, and the most primitive member, the Miihkali metalavas, are distinctly non-MORB like.

No directly pre-tectonic relationships between the syenites and the other members of the Outokumpu assemblage are preserved, but the pyroxenites and the possibly related chloritized dykes have quite clear relationships to the serpentinized ultramafic sills. Some of the pyroxenites at Louhilampi contain the high temperature hornfels assemblage considered to be part of the thermal aureole to these sills (Park, 1983), while the dykes cut the serpentinites, the country rocks and the contact between the two. The simplest interpretation would imply that the syenites, pyroxenites and serpentinized ultramafic sills were broadly contemporaneous. For the metagabbros and Rantala amphibolite no pre-tectonic relationships are preserved, and geochemical characteristics alone imply a relationship to the mafic metavolcanic rocks. The interpretation preferred here is that they represent sub-volcanic intrusions (see revised stratigraphy for the Outokumpu assemblage, Fig. 10). The radiometric age for the Outokumpu assemblage is based on U-Pb dating of zircon from the Horsmanaho gabbro $(1,972 \pm 18$ Ma, Huhma, 1986). If this metagabbro is related to the metagabbros, hornblendites and Rantala amphibolite described here, then this is the age of the mafic volcanism in the assemblage.

Two possible tectonic settings can be envisaged for the Outokumpu assemblage:

1. The syenites and pyroxenites represent extremely evolved members of a shoshonite suite that includes the mafic metalavas of the Outokumpu assemblage and their related doleritic and gabbroic minor intrusions. In this scenario, the Outokumpu assemblage is the remnant of a c. 1970 Ma old intra-oceanic arc (cf. Park, 1988a, 1991).

2. The doleritic and gabbroic minor intrusions are related to the mafic metalavas of the Outo- 


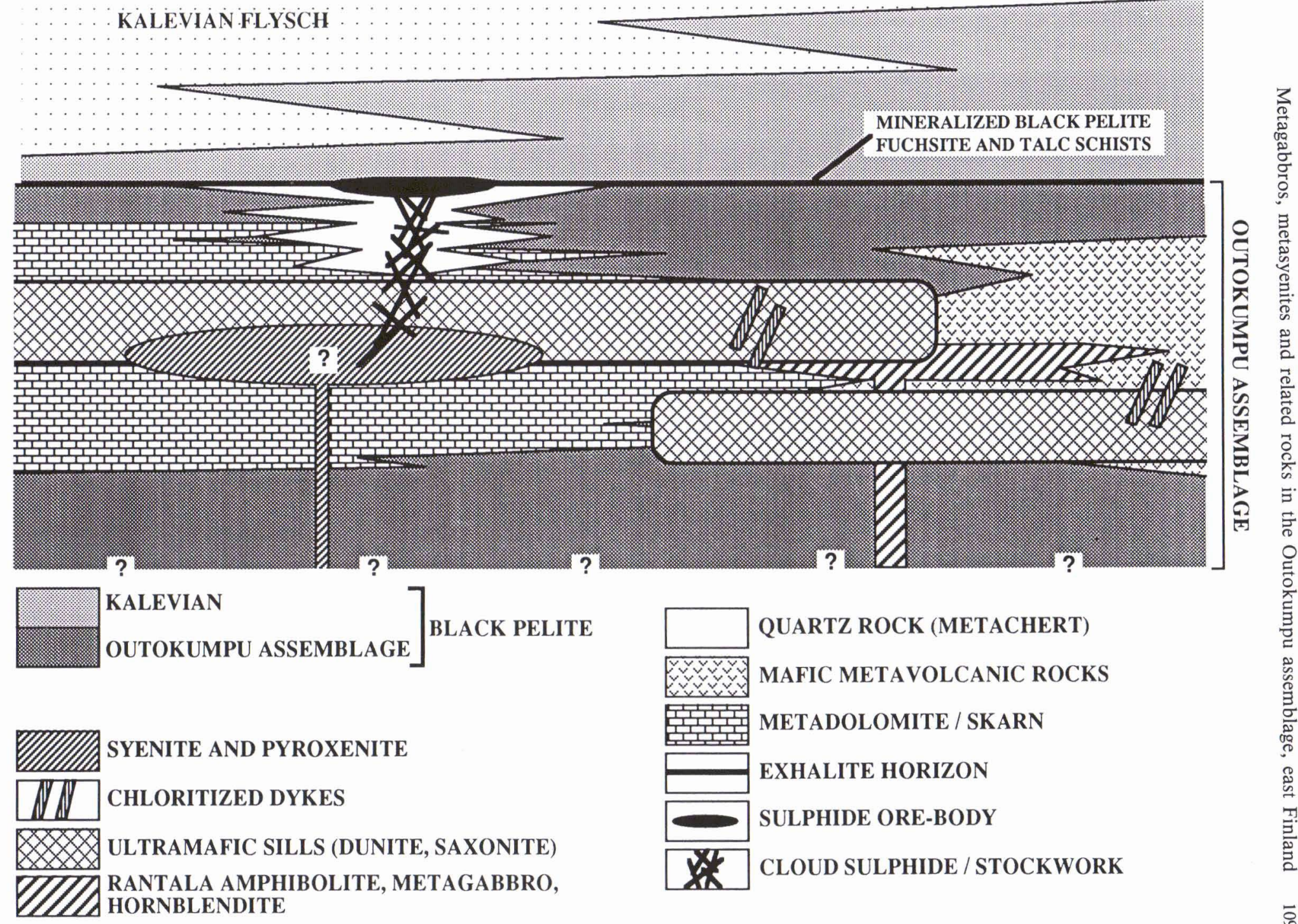

Fig. 10. Stratigraphy for the Outokumpu assemblage showing the position of the metagabbros and their relatives, and the shoshonite - shonkinites. Revised after Park (1988a). 
kumpu assemblage, while the shoshonitic syenites and pyroxenites relate to a superimposed or tectonically incorporated igneous province. In this scenario, the Outokumpu assemblage is the remnant of a hybrid terrane that includes a c. 1970 Ma old intra-oceanic arc.

Remnants of pre-tectonic intrusive relationships suggests that the first option is the more realistic of the two. The nature of the basement to this arc remains elusive. Neither of these options rules out the possibility, indeed probability, that the Outokumpu assemblage formed on a young oceanic basement, perhaps the lateral equivalent of the Jormua ophiolite (Kontinen, 1987; Park, 1988a, 1991). None of this, or any other basement occurs in the Outokumpu nappe, so though attractive as a model, it remains an unproven possibility.

Acknowledgements. Facilities for field work, access to drillcore and exploration data were provided for the author by Myllykoski Oy and Outokumpu Oy, and receipt of these is gratefully acknowledged, as is financial support from the University of Glasgow Research Support Fund. The author would like to thank Frederik Bjönberg, Pertti Huopaniemi, Matti Tyni, Kurt Karlsson, Don Bowes, Tapio Koistinen, Norman Halden and Peter Ward for their help, encouragement and criticism. Hannu Huhma is thanked for a helpful and critical review of the manuscript. Facilities permitting completion of the writing up of this material were provided by the Department of Geology, University of New Brunswick, while the author held a post-doctoral research fellowship.

\section{References}

Borodin, L.S. \& Pavlenko, A.S. 1974. The role of metasomatic processes in the formation of alkaline rocks. In Sørensen, H. (ed.) The Alkaline Rocks. Wiley, London, pp. 515-534.

Corriveau, L. 1990. Proterozoic subduction and terrane amalgamation in the southwestern Grenville province, Canada: evidence from ultrapotassic to shoshonitic plutonism. Geology, 15, 614-617.

Eskelinen, E., Huopaniemi, P. \& Tyni, M., Myllykoski Oy:n Luikonlahden kuparikaivos 1968-83 (with English summary) Eripainos Vuoriteollisuus-Bergshanteringen, 2, 94-98.

Eskola, P. \& Sahama, Th. G. 1930. On astrophyllite-bearing nephelite syenite gneiss found as a boulder in Kiihtelysvaara, East Finland. Bull. Comm. géol. Finlande, 92, $77-88$.

Foley, S.F., Venturelli, G., Green, D.H. \& Toscani, L. 1987. The ultrapotassic rocks: characteristics, classification and constraints for petrogenetic models. Earth Sci. Rev., 24, $81-134$.

Gaál, G., 1990. Tectonic styles of early Proterozoic ore deposition in the Fennoscandian shield. Precambrian Res., 46, $83-114$.

-, Koistinen, T.J. \& Mattila, E., 1975. Tectonics and stratigraphy of the vicinity of Outokumpu, north Karelia, Finland. Geol. Surv. Finland Bull., 271, 67 p.

Goodwin, L.B. \& Wenk, H-R., 1990. Intracrystalline folding and cataclasis in biotite of the Santa Rosa mylonite zone: HVEM and TEM observations. Tectonophysics, $172,201-214$.

Hofmann, A.W., 1988. Chemical differentiation of the Earth: the relationship between mantle, continental crust and oceanic crust. Earth Planet. Sci. Lett., 90, 297-314.

Haapala, P., 1936. On serpentinite rocks in northern Karelia. Bull. Comm. géol. Finlande, 114, 83 p.

Harvey, P.K. \& Atkins, B.P., 1982. The estimation of mass absorption coefficients by Compton scattering-extensions of the use of $\mathrm{Rh} \mathrm{K}_{\alpha}$ Compton radiation and intensity ratio. Am. Mineral., 62, 534-537.

Huhma, A., 1971. Suomen Geologinen Yleiskartta $1: 100,000$ Lehti 4222, 4224, 4311; Sivakkavaara, Polvijärvi, Outokumpu. Suomen Geologinen Tutkimuslaitos; Otaniemi.

— \& Huhma, M. 1970. Contributions to the geology and geochemistry of the Outokumpu region. Geol. Soc. Finland Bull., 42, 59-87.

Huhma, H., 1986. Sm-Nd, U-Pb and $\mathrm{Pb}-\mathrm{Pb}$ isotopic evidence for the origin of the early Proterozoic Svecokarelian crust in Finland. Geol. Surv. Finland Bull., 337, 52 p.

- 1987. Provenance of Early Proterozoic and Archaean metasediments in Finland: a Sm-Nd isotopic study. Precambrian Res., 35, 127-143.

Koark, H.J., 1969. Zu Hülle, Inhalt, Gefüge und Alter des Alkaligesteinsvorkommen von Norra Kärr in südlichen Mittelschweden. Geol. Fören. Stockholm Förh., 91, 159-18.

Koistinen, T.J., 1981. Structural evolution of an early Proterozoic stratabound $\mathrm{Cu}-\mathrm{Co}-\mathrm{Zn}$ deposit, Outokumpu, Finland. Trans. R. Soc. Edinburgh Earth Sci., 72, 115-158.

Kontinen, A., 1987. An early Proterozoic ophiolite - the Jormua mafic-ultramafic complex, northeastern Finland. Precambrian Res., 35, 313-341.

Langworthy, A.P. \& Black, L.P., 1978. The Mordor Com- 
plex: a highly differentiated potassic intrusion with kimberlitic affinities in central Australia. Contrib. Mineral. Petrol., 67, 51-62.

Le Bas, M.J., 1987. Nephelinites and carbonatites, In Fitton, J.G. and Upton, B.G.J. (eds) Alkaline Igneous Rocks, Geol. Soc. London Spec. Publ. 30, pp 53-83.

Marmo, V., Hoffrén, V., Hytonen, K., Kallio, P., Lindholm, O. \& Siivola, J., 1966. On the granites of Honkamäki and Otanmäki, Finland. Bull. Comm. géol. Finlande, 221.

Nash, W.P. \& Wilkinson, J.F.G., 1970. Shonkin Sag laccolith, Montana: I. Mafic minerals and estimates of temperature, pressure, oxygen fugacity and silica activity. Contrib. Mineral. Petrol., 25, 241-269.

-, 1971. Shonkin Sag laccolith, Montana: II. Bulk rock geochemistry. Contrib. Mineral. Petrol., 33, 162-170.

Park, A.F., 1983. Sequential development of metamorphic fabric and structural elements in polyphase deformed serpentinites in the Svecokarelides of eastern Finland. Trans. R. Soc. Edinburgh Earth Sci., 74, 33-60.

$\ldots, 1984$. Nature, affinities and significance of metavolcanic rocks in the Outokumpu assemblage, eastern Finland. Geol. Soc. Finland Bull., 56, 25-52.

-, 1988a. Nature of the early Proterozoic Outokumpu assemblage, eastern Finland. Precambrian Res., 38, 131146.

,$- 1988 \mathrm{~b}$. Geometry of sheath folds and related fabrics at the Luikonlahti mine, Svecokarelides, eastern Finland. J. Struct. Geol., 10, 487-498.

-, 1991. Continental growth by accretion: a tectonostratigraphic terrane analysis of the evolution of the western and central Baltic Shield 2.50-1.75 Ga ago. Geol. Soc. America Bull., 103, 522-537.

Puustinen, K., 1971. Geology of the Siilinjärvi carbonatite complex, eastern Finland. Bull. Comm. géol. Finlande, 249.

Rehtijärvi, P. \& Saastamoinen, J., 1985. Tectonised actinolitealbite rocks from the Outokumpu district, Finland: field and geochemical evidence for mafic volcanism. Geol. Soc. Finland Bull., 57, 47-54.
Streckeisen, A. \& LeMaitre, R.W., 1979. A chemical approximation to the modal QAPF classification of the igneous rocks. Neues Jahr. Mineral. Abh., 136, 169-206.

Sun, S-S., 1980. Lead isotopic study of young volcanic rocks from mid-ocean ridges, ocean islands and island arcs. Phil. Trans. R. Soc. London, A297, 409-445.

Sutherland, D.S., 1982. Alkaline intrusions of north-western Scotland. In Sutherland, D.S. (ed.) Igneous Rocks of the British Isles. Wiley-Interscience, London, pp. 203-216.

Thirlwall, M.F. \& Burnard, P., 1990. Pb-Sr-Nd isotope and chemical study of the origin of undersaturated and oversaturated shoshonitic magmas from the Borralan pluton, Assynt, NW Scotland. J. Geol. Soc. London, 147, 259269.

Treloar, P.J., 1987. The Cr-minerals of Outokumpu - their chemistry and significance. J. Petrol., 28, 867-886.

Vaasjoki, M., 1981. The lead isotopic composition of some Finnish galenas. Geol. Surv. Finland Bull., 316.

Vähätalo, V.O., 1953. On the geology of the Outokumpu ore deposit, Finland. Bull. Comm. géol. Finlande, 164.

Väyrynen, H., 1939. On the geology and tectonics of the Outokumpu ore field and region. Bull. Comm. géol. Finlande, 124.

Vuollo, J. \& Piirainen, T., 1989. Mineralogical evidence for an ophiolite from the Outokumpu serpentinites in North Karelia, Finland. Geol. Soc. Finland Bull., 61, 95-112.

Ward, $P$., 1987. Early Proterozoic deposition and deformation at the Karelian craton margin in southeastern Finland. Precambrian Res., 35, 71-93.

_, 1988. Early Proterozoic Kalevian lithofacies and their interpretation in the Hammaslahti - Rääkkylä area, eastern Finland. In Laajoki, K. and Paakkola, J. (eds) Sedimentology of the Precambrian Formations in Eastern and Northern Finland. Geol. Surv. Finland Spec. Pap. $5,29-48$.

Received February 24, 1992

Revision accepted May 20, 1992 